\title{
Holistic soccer profile by position: a theoretical framework
}

rewiev paper

(c) Wroclaw University of Health and Sport Sciences

DOI: https://doi.org/10.5114/hm.2023.110751

\section{TOMÁS MOTA ${ }^{1 \oplus}$, RUI SILVA ${ }^{2 \oplus}$, FILIPE MANUEL CLEMENTE ${ }^{2,3 \oplus}$}

${ }^{1} \operatorname{CSCS}^{*} \mathrm{D}$, Independent Researcher, Lisbon, Portugal

${ }^{2}$ Escola Superior Desporto e Lazer, Instituto Politécnico de Viana do Castelo, Viana do Castelo, Portugal

${ }^{3}$ Instituto de Telecomunicações, Delegação da Covilhã, Covilhã, Portugal

\section{ABSTRACT}

This article provides a holistic framework for the development of the technical, tactical, and fitness capacities required in soccer. It summarizes and organizes the main tactical and technical characteristics and the common physical demands of the game in accordance with different playing positions. Moreover, the typical fitness values found by playing positions are reviewed. A theoretical framework for a more individualized and specific training that integrates technical and tactical dimensions as well as fitness dimensions is proposed. Thus, through the identification of the main moments in a football game, a profile characterization of the contents for each capacity in each moment for all playing positions is presented and described.

Key words: association football, performance, individualization, sports training

\section{Introduction}

From a social interaction perspective, soccer should be defined as a short-term dynamic complex system [1], in which players share concrete interaction patterns that enable them to understand one another's playing-task-related messages while modifying their own actions depending on one another's intentions [2]. Notwithstanding, in a soccer match, confrontations between two coordinated dynamic complex systems are expected [3]. Such confrontations are characterized by the nature of order versus disorder and must be controlled with the intention of maintaining order within the team while instigating disorder in the opposing team [4].

Thus, at the inter-team level, fluctuations in the configuration of play are expected owing to the perceived interactions and behaviours of the opposing team that must be anticipated to (re)adjust the organization of the system on the field. On the basis of such behaviours, the team may expand or contract the effective play space in response to the momentary disorder caused by the opponents [4]. On the other hand, at the intra-team level, the positioning of teammates on the field, the ball path, and the game speed affect players' interactions, which, in turn, impact on decision making. In such cases, the respect for the game principles occupies a dynamic guiding role while promoting the use of an organized system that disrupts the opponent's system structure at the same time [3, 4].

By being aware of these sensitive influences among players' behaviour patterns, soccer teams can cope with different tactical behaviours in accordance with the positional roles and specific demands [5]; their dynamic coordinated actions may also be influenced by their position role on the field, which affects players' decision [6]. Thus, in a soccer match, teams can have higher or lower dispersion values, depending on their offensive and defensive principles. However, a decline in players' abilities to ensure optimal tactical behaviours through spatiotemporal interactions is to be expected in the second half of a soccer match because of fatigue [7].

Owing to the dynamic complex system nature of soccer, its characteristic interaction patterns and the principles of play seem to have a direct impact on the

Correspondence address: Filipe Manuel Clemente, Escola Superior Desporto e Lazer, Instituto Politécnico de Viana do Castelo, Rua Escola Industrial e Comercial de Nun'Álvares, 4900-347 Viana do Castelo, Portugal, e-mail: filipe.clemente5@gmail.com, https://orcid.org/0000-0001-9813-2842

Received: July 4, 2020

Accepted for publication: August 17, 2021

Citation: Mota T, Silva R, Clemente FM. Holistic soccer profile by position: a theoretical framework. Hum Mov. 2023;24(1):4-20; doi: https://doi.org/10.5114/hm.2023.110751. 
tactical behaviour of players [8], as well as on the model of play adopted by coaches, playing formations, and development of younger players [9]. These factors can either limit or augment the technical and physical characteristics of players and their activity profiles with and without ball possession [10].

Additionally, real-world information and models produced surrounding player-positional attributes could help both coaches and recruitment staff to implement and develop youth talent selection programs $[9,11]$.

With these specific characteristics within positional roles and different behaviour patterns, the aim of this article is to discuss and propose a profile characterization of the contents for each capacity in each moment and a theoretical framework for a more individualized and specific training that integrates technical and tactical dimensions as well as fitness dimensions. Thus, the following topics and sections are presented: (i) introduction to the key concepts of the dynamic complex system of soccer; (ii) the moments and principles of play; (iii) specific demands of playing positions; (iv) the model; and (v) conclusions. Ultimately, the aim of the paper is to propose practical guidelines so that coaches can decide on a more substantiated and researched base.

\section{Material and methods}

In this section, the authors mainly expose the rationale behind the selection of the articles that provide the theoretical basis for the framework/model. The current research represents a narrative review and not a systematic review. Thus, no specific search strategy was used systematically.

The scientific content presented in the paper was elaborated with the most related literature and there was a focus that each section, table, and the model itself were based on the available and most applicable research. The objective was to provide the reader with a comprehensive contextualization of the specific characteristics (mainly individualization aspects) before introducing the model/framework proposal.

The 66 used references were mainly collected through a focus that balanced between relevance and chronological date of release. Since the major emphasis of the article is the individual characterization of each position, we will consider the sections on the specific demands of playing positions and on the model as the main parts of the study.

In the former one, the applied references were collected on the basis of the typical relevance of the load imposed by playing positions, with the mean param- eter values and intervals of confidence of the selected articles provided. We also assumed to gather a minimum of 3 articles and a maximum of 8 articles for each measure of the presented tables. For the inclusion criteria of the cardiorespiratory and physical capacities and for the external load measures, only the studies that categorized their samples by playing position were considered; all reports that did not specify at least 3 different positions were excluded.

In the model section, the 17 references were selected by a search with the main keywords that could characterize each position. For example, for constructing the proposed model of the goalkeeper position, the authors extensively searched mainly Google Scholar by the keywords "goalkeeper + physical attributes; goalkeeper + technical attributes; goalkeeper + tactical attributes; goalkeeper + profile”.

\section{The moments and principles of play: why and how to follow them}

Following the aforementioned dynamic open-system-based reasoning, it is necessary to build logical thinking about the game itself, which guides players toward the division of the system into the methodological and organized subsystems [12]. In those subsystems, the players' interactions express general coordination and articulations of the different sectors through the temporal synchronization of their behaviours, thus creating several options for solving problems that are inherent to the game. These dynamically organized interactions of the methodological subsystem lead to the execution of 2 moments: (1) offensive methods (attack) and (2) defensive methods (defence) $[12,13]$.

The relational subsystem, which includes the principles of play, is derived from the methodological subsystem of soccer [12]. The principles in soccer constitute a toolbox of tactical actions that are inherent to the game moments as well as to the game model adopted by coaches. Furthermore, they are intended to facilitate tactical behaviours and interactions among players, allowing them to execute what the game requires by giving solutions to the game problems [14-16]. Table 1 summarizes the fundamental tactical principles.

Within this complex system, the structural subsystem can be further distinguished, in which a double dimension is observed. In this subsystem, the team starts from a 'static' dimension (4-3-3, 4-4-2, and 4-5-1) and gives life to that static structure by defining the tactical tasks assigned to players depending on the selected structure [12]. 
T. Mota, R. Silva, F.M. Clemente, Holistic soccer profile by position

Table 1. Tactical principles and their related definitions

\begin{tabular}{|c|c|c|c|}
\hline \multicolumn{2}{|r|}{ ATTACK } & \multicolumn{2}{|r|}{ DEFENCE } \\
\hline Principle & Definition & Principle & Definition \\
\hline Penetration & $\begin{array}{l}\text { Actions that enable progression towards } \\
\text { goal through destabilization of opponent's } \\
\text { defensive line with creation of spaces } \\
\text { and numerical superiority }\end{array}$ & Delay & $\begin{array}{l}\text { Actions to decrease the space of the attacker } \\
\text { in possession and impeding dribbling } \\
\text { or passing actions that allows the defence } \\
\text { to have time to organize }\end{array}$ \\
\hline $\begin{array}{l}\text { Offensive } \\
\text { coverage }\end{array}$ & $\begin{array}{l}\text { Supportive actions to the player in pos- } \\
\text { session decreasing pressure by creating } \\
\text { numerical superiority and increasing } \\
\text { players' confidence by ensuring first } \\
\text { defensive action when losing possession }\end{array}$ & $\begin{array}{l}\text { Defensive } \\
\text { coverage }\end{array}$ & $\begin{array}{l}\text { Supportive actions to the player in delay } \\
\text { process increasing pressure on offensive } \\
\text { player by decreasing his options and } \\
\text { ensuring a new obstacle to be overcome }\end{array}$ \\
\hline Width/Length & $\begin{array}{l}\text { Dispersion of players in attack without } \\
\text { ball that explore wider and deeper spaces } \\
\text { to allow greater and safer offensive options } \\
\text { that may cause decision making more } \\
\text { difficult for opponent's defence }\end{array}$ & Balance & $\begin{array}{l}\text { Creation of defensive superiority } \\
\text { and the ability to adjust positioning } \\
\text { to offensive actions, ensuring defensive } \\
\text { stability that supports players in delay } \\
\text { and defensive coverage }\end{array}$ \\
\hline Mobility & $\begin{array}{l}\text { Movements of the players without ball } \\
\text { that allow to receive the ball in the back } \\
\text { of defensive line through deep passes } \\
\text { and the rupture of defensive structure }\end{array}$ & Concentration & $\begin{array}{l}\text { Gathering defence to protect vital zones } \\
\text { from progression of offensive actions, } \\
\text { direct play to less vital zones, and allow } \\
\text { for a regain of ball possession }\end{array}$ \\
\hline Offensive unity & $\begin{array}{l}\text { Actions requiring all sectors to move } \\
\text { to the offensive midfield ensuring more } \\
\text { players in game epicentre for supportive } \\
\text { actions that allow for a more organized } \\
\text { and safer transition to defence when losing } \\
\text { possession }\end{array}$ & $\begin{array}{l}\text { Defensive } \\
\text { unity }\end{array}$ & $\begin{array}{l}\text { Actions that limit offensive progression } \\
\text { through coordinated interactions } \\
\text { that allow to perform the offside rule, } \\
\text { reduce space, and ensure more players } \\
\text { in the epicentre of play }\end{array}$ \\
\hline
\end{tabular}

Regarding the physical demands of a soccer match and in accordance with its dynamic complex system nature, it is imperative to broaden players' knowledge about the demands of different positions in relation to the formations [17] used in the game model chosen by coaches. Notwithstanding the aforementioned differences, similarities have been demonstrated in the overall distance covered between offensive and defensive formations [10, 17]. However, when scrutinizing the possible scenarios of using different formations and their impact on playing positions, it may be possible to observe that different types of tactical behaviours influence the physical demands of each player $[10,17]$. Table 2 presents the potential links between moments of play and physical demands.

From the dynamic complex system point of view, it is evident that in soccer, whether in training or in a match, many interactions come into play that express varied forms of behaviour patterns between and within teams [16]. Therefore, it is essential to invoke the physical demands that come from these interactions at the system and subsystem levels [17].

\section{Specific demands: individualization as a key factor}

In an elite soccer team, players have to deal with dynamic motions that can be imperative to the final result of a match [18]. Therefore, they can expect to cover approximately 10,000-13,000 m per match [19] and approximately $4500-7000 \mathrm{~m}$ per training session. Of these distances, elite soccer players can cover up to approximately $1000 \mathrm{~m}$ while high-speed running $\left(19.8-24.9 \mathrm{~km} \cdot \mathrm{h}^{-1}\right)$ and up to approximately $400 \mathrm{~m}$ at a sprinting speed $\left(>25 \mathrm{~km} \cdot \mathrm{h}^{-1}\right)$ [20], achieving maximal speeds of $25-33 \mathrm{~km} \cdot \mathrm{h}^{-1}$ during training sessions and competitive matches [20-24]. Also, they need to change velocity as fast as possible. Thus, the acceleration and deceleration profile of a soccer team must be taken into account to ensure the appropriate management of player load [25].

Naturally, such demands and conditions should be considered at the age-group level, mainly because in youth categories, the demands are smaller, although similarly distributed in intensity levels [26]. Adjust- 
Table 2. Moments of play and the physical demands in accordance with playing formations

\begin{tabular}{|c|c|c|c|c|c|}
\hline \multicolumn{3}{|c|}{ Moment of play } & \multicolumn{2}{|c|}{ Definition } & Physical demands \\
\hline \multicolumn{3}{|c|}{ Offensive organization } & \multicolumn{2}{|c|}{$\begin{array}{l}\text { Coordinated behaviours in possession } \\
\text { aiming at the construction, creation, and } \\
\text { finalization subphases of offensive actions }\end{array}$} & - \\
\hline \multicolumn{3}{|c|}{ Offensive transition } & \multicolumn{2}{|c|}{$\begin{array}{l}\text { Moment from which the team that regains } \\
\text { possession and takes advantage of the } \\
\text { opponent's disorganization starts the } \\
\text { offensive actions as fast as possible }\end{array}$} & $\begin{array}{l}\text { - Fast change of direction } \\
\text { - Greater sprint velocities } \\
\text { - Greater fast reaction to possession }\end{array}$ \\
\hline \multicolumn{3}{|c|}{ Offensive formations } & \multicolumn{2}{|c|}{$4-3-3$ and $4-4-2$} & $\begin{array}{l}\text { - Greater distances jogging }\left(7.2-14.3 \mathrm{~km} \cdot \mathrm{h}^{-1}\right) \\
\text { - Greater VHIR }\left(19.8-25.1 \mathrm{~km} \cdot \mathrm{h}^{-1}\right) \text { with ball } \\
\text { possession }\end{array}$ \\
\hline \multicolumn{3}{|c|}{ Defensive organization } & \multicolumn{2}{|c|}{$\begin{array}{l}\text { Coordinated behaviours without possession } \\
\text { aiming at impeding the construction, creation, } \\
\text { and finalization subphases of opponent's } \\
\text { offensive actions, preventing the goal }\end{array}$} & - \\
\hline \multicolumn{3}{|c|}{ Defensive transition } & \multicolumn{2}{|c|}{$\begin{array}{l}\text { Moment from which the team that lost } \\
\text { possession starts to impede offensive } \\
\text { progression and, at the same time, } \\
\text { to organize defence structure }\end{array}$} & $\begin{array}{l}\text { - Fast change of direction } \\
\text { - Greater sprint velocities } \\
\text { - Greater fast reaction to loss of possession }\end{array}$ \\
\hline \multirow{2}{*}{\multicolumn{3}{|c|}{ Defensive formations }} & \multicolumn{2}{|l|}{$4-5-1$} & $\begin{array}{l}\text { - Greater distances walking }\left(0.7-7.1 \mathrm{~km} \cdot \mathrm{h}^{-1}\right) \\
\text { - Greater VHIR without possession }\end{array}$ \\
\hline & & & Defend & Midfielders & Attackers \\
\hline \multirow{3}{*}{ 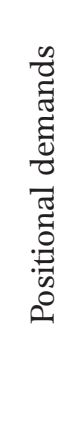 } & $4-3-3$ & \multicolumn{3}{|c|}{$\begin{array}{l}\text { - Less TD covered } \\
\text { - Less VHIR } \\
\text { - More HIR and VHIR in the } 1^{\text {st }} \text { half }\end{array}$} & $\begin{array}{l}\text { - More HIR and VHIR } \\
\text { - More HIR in the } 1^{\text {st }} \text { half }\end{array}$ \\
\hline & $4-4-2$ & \multicolumn{2}{|c|}{$\begin{array}{l}\text { - More TD covered } \\
\text { - More HIR } \\
\text { - More VHIR }\end{array}$} & - More VHIR & - Less HIR and VHIR \\
\hline & $4-5-1$ & \multicolumn{2}{|c|}{$\begin{array}{l}\text { - Less TD covered } \\
\text { - Less HIR } \\
\text { - Less VHIR }\end{array}$} & - More VHIR & - Less HIR and VHIR \\
\hline
\end{tabular}

VHIR - very high intensity running, TD - total distance, HIR - high intensity running

ments of training stimuli and load should therefore involve the specificities of age group and, at youth stages, the maturation status of the players [27].

However, for the sake of managing player load, coaches would benefit from a better understanding of all the specific demands related to the different playing positions, as this would allow them to individualize training with more accuracy. Data regarding the physical demands by position from professional elite soccer players were gathered from the literature, for each variable. Table 3 summarizes the typical physical demands that occur in a match in the particular playing positions.

All players cover approximately the same total distance during a soccer match, with forwards covering the shortest distances. Although the average total distance covered is lower for the forwards, the maximum value of the total distance covered in this position $(11,254 \mathrm{~m})$ is the same as it is for other positions. On the other hand, central defenders cover the shortest total distance with regard to the maximum value registered $(10,627 \mathrm{~m})$ when compared with all other positions.

The differences found between the minimum and maximum values in some of the playing positions can be explained by the fact that coaches use different team formations on the field and different game models, which may influence the distances covered in each position. For instance, Bradley et al. [10] analysed the effects of soccer playing formations on high-intensity running profiles and technical performance and found 
T. Mota, R. Silva, F.M. Clemente, Holistic soccer profile by position

Table 3. Descriptive statistics (mean [min.; max.]) of total distance; distances covered at running speed, high speed running, and sprint; maximum speed; and number of high accelerations and decelerations across playing positions

\begin{tabular}{lccccc}
\hline Parameter & ED & CD & MF & W & FW \\
\hline TD $(\mathrm{m})$ & 11,064 & 10,058 & 10,910 & 11,672 & 9881 \\
{$[18,23,24,28-32]$} & {$[10,152 ; 11,451]$} & {$[9669 ; 10,627]$} & {$[8943 ; 12,027]$} & {$[10,523 ; 12,320]$} & {$[7733 ; 11,254]$} \\
\hline RUN $(\mathrm{m})$ & 2224 & 1500 & 1929 & 2386 & 1481 \\
{$[18,23,24,28-31]$} & {$[1730 ; 2892]$} & {$[1197 ; 1885]$} & {$[828 ; 3051]$} & {$[1987 ; 3138]$} & {$[563 ; 2341]$} \\
\hline HSR $(\mathrm{m})$ & 874 & 488 & 665 & 938 & 677 \\
{$[18,23,24,30-33]$} & {$[340 ; 1138]$} & {$[180 ; 605]$} & {$[253 ; 927]$} & {$[354 ; 1214]$} & {$[269 ; 955]$} \\
\hline SPRINT $(\mathrm{m})$ & 291 & 154 & 186 & 299 & 255 \\
{$[21,23,24,30,31,33-35]$} & {$[241 ; 374]$} & {$[110 ; 199]$} & {$[152 ; 228]$} & {$[235 ; 346]$} & {$[181 ; 345]$} \\
\hline MaxSpeed $\left(\mathrm{m} \cdot \mathrm{s}^{-1}\right)$ & 8.5 & 8.4 & 8.2 & 8.6 & 8.7 \\
{$[21-24]$} & {$[7.7 ; 9.0]$} & {$[7.3 ; 8.8]$} & {$[7.5 ; 8.6]$} & {$[7.9 ; 9.1]$} & {$[7.8 ; 9.2]$} \\
\hline High ACC $(n)$ & 34 & 27 & 33 & 35 & 38 \\
{$[32]^{*}$} & {$[34 ; 34]$} & {$[27 ; 27]$} & {$[33 ; 33]$} & {$[35 ; 35]$} & {$[38 ; 38]$} \\
\hline High DCC $(n)$ & 56 & 45 & 53 & 62 & 55 \\
{$[32]^{*}$} & {$[56 ; 56]$} & {$[45 ; 45]$} & {$[53 ; 53]$} & {$[62 ; 62]$} & {$[55 ; 55]$} \\
\hline
\end{tabular}

ED - external defender, CD - central defender, MF - midfielder, W - winger, FW - forward, TD - total distance, RUN - running, HSR - high speed running, MaxSpeed - maximum speed, ACC - acceleration, DCC - deceleration The mean [min.; max.] values were calculated by integrating the reported values from the included studies.

* Only one study found for the selected variable.

that forwards covered approximately $30 \%$ more distance at high-intensity running in a 4-3-3 formation than in 4-4-2 and 4-5-1 formations. This indicates that although the overall activity profiles of players are not affected by playing formations, high-intensity running activity may be influenced.

The distances covered at running speed (14-19.8 $\mathrm{km} \cdot \mathrm{h}^{-1}$ ) are more prominent in external defenders and wingers; the same is the case for distances covered during high-speed running $\left(19.8-24.9 \mathrm{~km} \cdot \mathrm{h}^{-1}\right)$. This may be explained by the greater distances that these players are required to cover and explore when compared with central defenders, midfielders, and forwards. In other words, the more centrally the players are positioned on the field, the smaller the distances they tend to cover during running, high-speed running, and sprinting. Likewise, external defenders, wingers, and forwards present greater distance of sprints, high accelerations, and high decelerations $\left(>3 \mathrm{~m} \cdot \mathrm{s}^{-2}\right)$ than central defenders and central midfielders. However, not many studies have compared the high acceleration and deceleration profiles of different playing positions. This makes it difficult to draw firm conclusions about the data presented here.

In contrast, when it comes to maximum speed $\left(\mathrm{m} \cdot \mathrm{s}^{-1}\right)$, all player positions show approximately the same average values. However, if the maximum val- ues are taken into account, the players who reach the highest values in a soccer match are forwards, wingers, and external defenders, probably because these players have a larger area to explore during a match.

From a performance perspective, the players positioned at the wider areas of a soccer field (e.g., external defenders and wingers) may need to cover longer distances at high-speed running and sprinting speeds, as well as to perform numerous high accelerations and decelerations, depending on the playing formation used by the coach. Forwards also cover great distances at sprint speeds despite their central position. Thus, these players would benefit from undergoing differentiated and individualized training stimuli based on their required demands with regard to the distances covered at different running speeds and intensities. Moreover, individualized training must be addressed to the more central players (e.g., central defenders and central midfielders), who would not benefit from the same training stimuli as players in wider positions from a practice perspective. Thus, footballers in wider positions would take advantage of performing longer sprints (i.e., over $30 \mathrm{~m}$ ) in an analytical fashion, which is not possible in small- or medium-sided games. Meanwhile, central defenders and central midfielders would benefit more from small- and medium-sided games than from activities that involve a lot of sprinting. 
Nevertheless, in addition to the distances covered at different speeds, elite soccer players have a welldefined physical capacity, showing a high average of $51-62.9 \mathrm{ml} \cdot \mathrm{kg}^{-1} \cdot \mathrm{min}^{-1}$ of maximal oxygen uptake $\left(\mathrm{VO}_{2} \mathrm{max}\right)$ [36-41] and maximal aerobic speeds of approximately $12-17 \mathrm{~km} \cdot \mathrm{h}^{-1}[36,37,39,42]$. In turn, lower limb maximal strength has been associated with performance improvements in jumping ability and sprinting times [43, 44]. For these reasons, particular attention should be given to positional differences regarding jump ability and sprint performance. Data regarding the fitness levels by position from professional elite soccer players were gathered from the literature, for each variable. Table 4 depicts the typical fitness levels of players depending on their playing position.

In general, all player positions present high $\mathrm{VO}_{2} \max$ values, excluding goalkeepers, which seems to be a natural consequence of the specific characteristics and demands of their position, not requiring large areas of the field to be explored throughout a soccer match. Midfielders have the highest values of $\mathrm{VO}_{2} \mathrm{max}$, followed by external defenders, which may be due to the link between the defensive and offensive sectors, forcing these players to have higher levels of physical fitness. However, when considering the lowest running speed at which $\mathrm{VO}_{2}$ max occurs (e.g., maximal aerobic speed), all players, excluding goalkeepers, present similar values.
Regarding the vertical impulse performance, goalkeepers, central defenders, and forward players perform better than external defenders and midfielders. Very few studies refer to the vertical jump performance of wingers, and only one study [37] has made a distinction between midfielders and wingers in this regard. The same limitations were found with reference to agility performance for different positions on the field; the players who completed the $10-\mathrm{m}$ and $30-\mathrm{m}$ sprints the fastest were external defenders and wingers, with small differences found among all other positions.

To the best of our knowledge, no study has investigated the lower limb maximal strength of soccer players across playing positions. Although Wisløff et al. [43] demonstrated that elite soccer players could lift approximately $170 \mathrm{~kg}$ on average, which corresponds to 2.2 times their body weight, these values are likely to be higher. The same authors [43] found strong correlations between maximal strength and 10-30-m sprinting and vertical jump performance.

\section{The model}

The proposed model was inspired and underpinned by different framework structures such the ones presented by Hughes et al. [54], Wiemeyer [55], Razali et al. [56], Roberts et al. [11], Berber et al. [9] and is divided into 2 phases: attacking and defensive. In each phase, the authors considered 3 moments, or subphases. In

Table 4. Descriptive statistics (mean [min.; max.]) of cardiorespiratory and physical capacities

\begin{tabular}{lcccccc}
\hline Parameter & GK & ED & $\mathrm{CD}$ & $\mathrm{MF}$ & $\mathrm{W}$ & $\mathrm{FW}$ \\
\hline $\mathrm{VO}_{2} \mathrm{max}\left(\mathrm{ml} \cdot \mathrm{kg}^{-1} \cdot \mathrm{min}^{-1}\right)$ & 54.1 & 59.4 & 57.5 & 61.2 & 58 & 59.2 \\
{$[36,37,39-41,45]$} & {$[51 ; 58.7]$} & {$[57.2 ; 61.5]$} & {$[52.3 ; 63.7]$} & {$[57.1 ; 64.2]$} & {$[58 ; 58]$} & {$[55.8 ; 62.9]$} \\
\hline $\mathrm{MAS}\left(\mathrm{km} \cdot \mathrm{h}^{-1}\right)$ & 14.2 & 15.4 & 15.3 & 15.9 & 16.5 & 15.3 \\
{$[36,37,39,42]$} & {$[12.7 ; 15.2]$} & {$[14.4 ; 16.5]$} & {$[13.4 ; 16.5]$} & {$[14.2 ; 16.9]$} & {$[16.5 ; 16.5]$} & {$[13.6 ; 16.2]$} \\
\hline $\mathrm{CMJ}(\mathrm{cm})$ & 39.7 & 40.4 & 44 & 38.6 & 45.7 & 41.4 \\
{$[36,37,46-51]$} & {$[30 ; 45.6]$} & {$[36.8 ; 43.5]$} & {$[37.3 ; 57.8]$} & {$[30 ; 47.7]$} & {$[45.7 ; 45.7]$} & {$[31 ; 56.4]$} \\
\hline $\mathrm{SJ}(\mathrm{cm})$ & 41.4 & 38.5 & 39.8 & 38.6 & 41.6 & 40.3 \\
{$[36,37,40,46,51,52]$} & {$[35.8 ; 0.8]$} & {$[34.8 ; 42.1]$} & {$[36.3 ; 42.4]$} & {$[36.1 ; 41.5]$} & {$[41.6 ; 41.6]$} & {$[36.7 ; 44.2]$} \\
\hline $10-\mathrm{m} \mathrm{sprint}(\mathrm{s})$ & 1.9 & 1.7 & 1.9 & 1.9 & 1.6 & 1.8 \\
{$[37,47,50,52]$} & {$[1.7 ; 2.4]$} & {$[1.7 ; 1.7]^{*}$} & {$[1.7 ; 2.1]$} & {$[1.7 ; 2.2]$} & {$[1.6 ; 1.6]^{*}$} & {$[1.7 ; 2]$} \\
\hline $30-\mathrm{m} \mathrm{sprint}(\mathrm{s})$ & 4.4 & 4.2 & 4.4 & 4.4 & - & 4.4 \\
{$[46,47,50,53]$} & {$[4.3 ; 4.5]$} & {$[4.2 ; 4.2]^{*}$} & {$[4.3 ; 4.6]$} & {$[4.3 ; 4.6]$} & - & {$[4.3 ; 4.6]$} \\
\hline
\end{tabular}

GK - goalkeeper, ED - external defender, CD - central defender, MF - midfielder, W - winger, FW - forward,

$\mathrm{VO}_{2}$ max - maximal oxygen uptake, MAS - maximal aerobic speed, CMJ - countermovement jump, SJ - squat jump

The mean [min.; max.] values were calculated by integrating the reported values from the included studies.

* Only one study found for the selected variable 
T. Mota, R. Silva, F.M. Clemente, Holistic soccer profile by position

Table 5. The model: table of concepts

\begin{tabular}{|c|c|c|c|}
\hline Concept & Description & Concept & Description \\
\hline \multicolumn{4}{|l|}{ TECHNICAL } \\
\hline Passing & $\begin{array}{l}\text { The act of passing the ball } \\
\text { to another player of the team }\end{array}$ & Throw & A pass made with a player's hand(s) \\
\hline Ball control with feet & $\begin{array}{l}\text { The skill of controlling and positioning } \\
\text { the ball in good conditions to continue } \\
\text { the play with the use of the feet }\end{array}$ & Kick & $\begin{array}{l}\text { The act of moving the ball with the use } \\
\text { of the feet }\end{array}$ \\
\hline Tackle & $\begin{array}{l}\text { An attempt to obtain possession from } \\
\text { an opponent whether by a challenge } \\
\text { or physical influence }\end{array}$ & Dribbling & $\begin{array}{l}\text { An action that is responsible for moving } \\
\text { the ball around the pitch without passing } \\
\text { the ball to other teammates using the feet }\end{array}$ \\
\hline Heading & $\begin{array}{l}\text { The act of touching the ball with } \\
\text { the player's head with the aim } \\
\text { of moving it to another place }\end{array}$ & Shot stopping & $\begin{array}{l}\text { The capability of avoiding a shot from } \\
\text { the opposite team }\end{array}$ \\
\hline Coordination & $\begin{array}{l}\text { The skill of coordinating the player's } \\
\text { body structure to achieve a certain } \\
\text { action or motion }\end{array}$ & Recovery & $\begin{array}{l}\text { The motion through which a player } \\
\text { recovers useful play space to operate } \\
\text { in a more efficient way }\end{array}$ \\
\hline Save & $\begin{array}{l}\text { An action towards avoiding } \\
\text { the ball going inside the goal }\end{array}$ & Speed & $\begin{array}{l}\text { The time that a player takes to complete } \\
\text { an action }\end{array}$ \\
\hline Punch & $\begin{array}{l}\text { An action only allowed to goalkeepers } \\
\text { of moving the ball away with their hands } \\
\text { in a punching motion }\end{array}$ & Shooting & $\begin{array}{l}\text { A touch aimed towards the goal with } \\
\text { the intention of scoring }\end{array}$ \\
\hline Long pass & $\begin{array}{l}\text { A pass that is executed with the intent } \\
\text { of moving the ball to a place normally } \\
\text { further from the teammate immediately } \\
\text { next to the player with the ball possession }\end{array}$ & $\begin{array}{l}\text { Passes in the } \\
\text { defensive third }\end{array}$ & $\begin{array}{l}\text { A pass that is made in the most rearward } \\
\text { third of the field }\end{array}$ \\
\hline Ball control & $\begin{array}{l}\text { The skill of controlling and positioning } \\
\text { the ball in good conditions to continue } \\
\text { the play with the use of any allowed } \\
\text { body part }\end{array}$ & Ball touches & $\begin{array}{l}\text { The action of touching the ball with } \\
\text { the intent of controlling or dribbling it }\end{array}$ \\
\hline Running with the ball & $\begin{array}{l}\text { The action of possessing the ball } \\
\text { and running simultaneously }\end{array}$ & Clearances & $\begin{array}{l}\text { The act of touching and moving the ball } \\
\text { with the intent of moving it away from } \\
\text { a dangerous situation in terms } \\
\text { of defensive phase }\end{array}$ \\
\hline Strong 1 to 1 play & $\begin{array}{l}\text { A skill that aids a player in solving } \\
1 \text { vs. } 1 \text { moments }\end{array}$ & Interceptions & $\begin{array}{l}\text { The moment when a player anticipates } \\
\text { a play and gets ball possession, either } \\
\text { in the defensive or in the attacking phase } \\
\text { of the game }\end{array}$ \\
\hline Support play & $\begin{array}{l}\text { The moment when a player works } \\
\text { towards helping the development } \\
\text { of the play }\end{array}$ & $\begin{array}{l}1 \text { to } 1 \text { play } \\
\text { and covering }\end{array}$ & $\begin{array}{l}\text { The capability of defending the space } \\
\text { and the opponent during an individual } \\
\text { duel }\end{array}$ \\
\hline Crossing & $\begin{array}{l}\text { The act of passing the ball from a more } \\
\text { external position to a more central one }\end{array}$ & $\begin{array}{l}\text { Defensive } \\
\text { header }\end{array}$ & $\begin{array}{l}\text { A header that occurs in the defensive } \\
\text { phase }\end{array}$ \\
\hline Aerial duels & $\begin{array}{l}\text { The capability of disputing the ball without } \\
\text { feet on the ground, or with the head }\end{array}$ & $\begin{array}{l}\text { Pressing } \\
\text { opposition }\end{array}$ & $\begin{array}{l}\text { The action of placing defensive pressure } \\
\text { against the opponent with the goal of } \\
\text { disturbing individual and/or team actions }\end{array}$ \\
\hline Forward pass & $\begin{array}{l}\text { A pass that is made from a more rearward } \\
\text { position to a more advanced position on } \\
\text { the field }\end{array}$ & Short pass & $\begin{array}{l}\text { A pass that is executed when the space } \\
\text { between } 2 \text { players is short }\end{array}$ \\
\hline
\end{tabular}




\begin{tabular}{|c|c|c|c|}
\hline Good technical skills & $\begin{array}{l}\text { The competence of possessing good } \\
\text { general skills that can assist the player } \\
\text { in dealing with the game moments in } \\
\text { technical terms }\end{array}$ & Ball reception & $\begin{array}{l}\text { The action of touching the ball with } \\
\text { the intent of controlling it }\end{array}$ \\
\hline Creativity & $\begin{array}{l}\text { The capability of creating actions } \\
\text { that can solve problems which are not } \\
\text { normally recognized }\end{array}$ & $\begin{array}{l}\text { Capability to } \\
\text { achieve and } \\
\text { shoot at the goal }\end{array}$ & $\begin{array}{l}\text { The skill to solve situations that finish } \\
\text { with an attempt of shooting the ball } \\
\text { at the goal }\end{array}$ \\
\hline Dribble pass & A pass preceded by a dribble action & $\begin{array}{l}\text { Pass in the } \\
\text { middle third }\end{array}$ & $\begin{array}{l}\text { A pass that is made in the central third } \\
\text { of the field }\end{array}$ \\
\hline $\begin{array}{l}\text { Passes to the left } \\
\text { and right }\end{array}$ & $\begin{array}{l}\text { The capability of executing passes to both } \\
\text { sides in the frontal plane of the player }\end{array}$ & Key pass & $\begin{array}{l}\text { A pass that can create a decisive or } \\
\text { potentially important team action }\end{array}$ \\
\hline Ball possession & $\begin{array}{l}\text { The moment that corresponds to the time } \\
\text { that a player has the ball in their control }\end{array}$ & Recoveries & $\begin{array}{l}\text { The action of recovering the ball } \\
\text { possession }\end{array}$ \\
\hline Ground duels & $\begin{array}{l}\text { The capability of disputing the ball with } \\
\text { feet on the ground }\end{array}$ & Backwards pass & $\begin{array}{l}\text { A pass that is made from more advanced } \\
\text { areas to more rearward ones }\end{array}$ \\
\hline Full-back cover & $\begin{array}{l}\text { The action to cover defensively the space } \\
\text { or the possible transitions after an action } \\
\text { made by a full-back or external defender }\end{array}$ & Tricks & $\begin{array}{l}\text { A skill that contemplates creativity and } \\
\text { can solve situations through high-level } \\
\text { technical actions }\end{array}$ \\
\hline $\begin{array}{l}\text { Good goal-getter } \\
\text { qualities }\end{array}$ & $\begin{array}{l}\text { A characteristic of players who make use } \\
\text { of or create goal opportunities }\end{array}$ & $\begin{array}{l}\text { Throwing } \\
\text { the ball back } \\
\text { into play }\end{array}$ & $\begin{array}{l}\text { The act of putting the ball back into } \\
\text { the game by using both hands }\end{array}$ \\
\hline Taking corners & $\begin{array}{l}\text { The act of taking the set piece when } \\
\text { the opponent is the last one to touch } \\
\text { the ball getting out of the pitch }\end{array}$ & Backing & $\begin{array}{l}\text { Backpedalling or backwards running } \\
\text { to achieve a more prepared and efficient } \\
\text { position to task at hand }\end{array}$ \\
\hline Carrying the ball & $\begin{array}{l}\text { The act of having the possession of the } \\
\text { ball and executing one task or movement }\end{array}$ & $\begin{array}{l}\text { Ability of } \\
\text { single play }\end{array}$ & $\begin{array}{l}\text { The skill of managing to create individual } \\
\text { plays and to finish or to create finishing } \\
\text { situations for teammates }\end{array}$ \\
\hline
\end{tabular}

Finishing

Putting an end to a play in a successful

way, that is to say, goal

TACTICAL

Vision The capability of seeing with accuracy the area and the players near the centre of the player action

\section{Organization}

The capability of setting up own and other teammates' positions and action towards a more organized collective play

\begin{tabular}{lll}
\hline Communication & $\begin{array}{l}\text { The action where players talk to one } \\
\text { another with the goal of comprehending } \\
\text { the game and deciding in a better way }\end{array}$ & $\begin{array}{l}\text { Vision - } \\
\text { awareness } \\
\text { of space }\end{array}$ \\
\hline Position play & $\begin{array}{l}\text { The capability of executing the asked } \\
\text { demands for each field position }\end{array}$ & Anticipation \\
\hline
\end{tabular}

Good view of the game Seeing and comprehending the game in a way that can help create or solve problems that arise during both phases
Running off the ball

Forcing offside A defensive phase moment that occurs through the movement of a position or a line towards achieving an opponent offside

Good flanks The capability of coordinating the movements of the field flanks with every position and action that occurs in that particular space

Being aware of the space and movement of players, so that the planning of the play can be facilitated

The skill of understanding the context and adapting the player's position to anticipate a moment that can be detrimental or beneficial to the team

The action of moving through the field in a way that contributes to a more efficient occupancy of space that can benefit every teammate 


\section{HUMAN MOVEMENT}

T. Mota, R. Silva, F.M. Clemente, Holistic soccer profile by position

\begin{tabular}{|c|c|c|c|}
\hline $\begin{array}{l}\text { Organizing and } \\
\text { anticipatory capabilities }\end{array}$ & $\begin{array}{l}\text { The capability of setting up own and } \\
\text { other teammates' positions and action } \\
\text { towards a more organized collective play } \\
\text { so that the probability of anticipating } \\
\text { detrimental events is decreased }\end{array}$ & When to cross & $\begin{array}{l}\text { The know-how of the timing to cross } \\
\text { the ball }\end{array}$ \\
\hline Passing & $\begin{array}{l}\text { Passing the ball with a purpose to } \\
\text { achieve the main goal of the group }\end{array}$ & Support play & $\begin{array}{l}\text { The moment when a player works towards } \\
\text { helping the development of the play }\end{array}$ \\
\hline $\begin{array}{l}\text { Behaviours within } \\
\text { the attacking third }\end{array}$ & $\begin{array}{l}\text { Positional and characteristic actions } \\
\text { of the position in the most advanced } \\
\text { third of the field }\end{array}$ & $\begin{array}{l}\text { Behaviours } \\
\text { within central } \\
\text { areas }\end{array}$ & $\begin{array}{l}\text { Positional and characteristic actions } \\
\text { of the position in the central area } \\
\text { of the field }\end{array}$ \\
\hline $\begin{array}{l}\text { Behaviours within } \\
\text { the defensive } \\
\text { and midfield thirds }\end{array}$ & $\begin{array}{l}\text { Positional and characteristic actions } \\
\text { of the position in the most rearward } \\
\text { and central third of the field }\end{array}$ & $\begin{array}{l}\text { Behaviours on } \\
\text { the right side of } \\
\text { the playing field }\end{array}$ & $\begin{array}{l}\text { Positional and characteristic actions } \\
\text { of the position in the right lateral extreme } \\
\text { of the field }\end{array}$ \\
\hline $\begin{array}{l}\text { Behaviours within } \\
\text { the midfield } \\
\text { and attacking thirds }\end{array}$ & $\begin{array}{l}\text { Positional and characteristic actions } \\
\text { of the position in the most advanced } \\
\text { and central third of the field }\end{array}$ & Attacking play & $\begin{array}{l}\text { The intent of participating in attacking } \\
\text { phase actions }\end{array}$ \\
\hline Ability to read game & $\begin{array}{l}\text { Capability of interpreting the references } \\
\text { of the game and adapting to the context }\end{array}$ & Decision making & $\begin{array}{l}\text { The act of choosing the best possible } \\
\text { decision while facing the environment }\end{array}$ \\
\hline \multicolumn{4}{|l|}{ PHYSICAL } \\
\hline Height & Structural/anthropometric height & Flexibility & $\begin{array}{l}\text { A measure of muscle range of motion; } \\
\text { has a static and a dynamic component }\end{array}$ \\
\hline Strength & The ability to produce force & Stamina & The capability of enduring physical effort \\
\hline Power & The ability to exert force at higher speeds & Speed & $\begin{array}{l}\text { The skills and abilities needed to achieve } \\
\text { high movement velocities }\end{array}$ \\
\hline Agility & $\begin{array}{l}\text { The skills and abilities needed to change } \\
\text { direction, velocity, or mode in response } \\
\text { to a stimulus }\end{array}$ & $\begin{array}{l}\text { Good running } \\
\text { capabilities }\end{array}$ & $\begin{array}{l}\text { The capability of using running skills } \\
\text { to efficiently move through the field }\end{array}$ \\
\hline Coordination & $\begin{array}{l}\text { The organization of the different elements } \\
\text { of the complex body or activity and } \\
\text { enabling them to work together effectively }\end{array}$ & $\begin{array}{l}\text { Good physical } \\
\text { condition }\end{array}$ & $\begin{array}{l}\text { The general ability to endure game } \\
\text { physical demands }\end{array}$ \\
\hline Reaction time & The time it takes to react to a stimulus & High velocity & $\begin{array}{l}\text { The skill of executing actions at a high } \\
\text { speed }\end{array}$ \\
\hline Acceleration & $\begin{array}{l}\text { Change in velocity of the body per unit } \\
\text { of time }\end{array}$ & & \\
\hline
\end{tabular}

Based on previous studies [57, 58]

\section{The goalkeeper}

each moment, they characterized each phase in terms of the players' technical, tactical, and physical capacities. The main concepts are described in Table 5 .

An important note is that this model constitutes an introduction to what could be considered a framework of the aforementioned characteristics, as the goal is to establish a structure that gives coaches and athletes a well-thought-out and scientific guideline for prescribing and administering a training plan.
According to several studies [9, 53-55, 59], the suggested profile of this position can be characterized by the framework presented in Table 6 .

As implied in the research, the goalkeeper should be balanced in terms of their technical skills, having qualities like passing and ball control, with well-developed feet to face the attacking phase of the game. During the defensive phase, the goalkeeper will benefit from having well-trained shot-stopping, coordination, and saving skills. In tactical aspects, it is important for goalkeepers to be consistent regarding their vision as well as organization and communication ca- 
Table 6. Training contents framework for the goalkeeper

\begin{tabular}{ll}
\hline ATTACKING PHASE \\
\hline Technical & Passing; Throw; Ball control with feet; Kick; Tackle; Hold the ball; Protect the ball; 1v1; Long balls; \\
& Handling; Initial distribution of the ball; Footwork \\
\hline Tactical & Vision; Organization; Communication; Distribution; Position play; Transition; Initiate build-up; \\
& Provide a safe passing option; Relieve pressure; Organize and coordinate team members; Positioning; \\
& Develop and maintain situation awareness; Maintain position in team structure; Maintain possession; \\
& Manage match tempo; Play in line with coach ethos; Delay attacks; Provide visual personal identification; \\
& Recognize/anticipate team member actions; Recognize/anticipate opposition actions; Understand \\
& coach’s intent; Spatial awareness
\end{tabular}

\begin{tabular}{ll}
\hline Physical & Height; Strength; Power; Agility; Coordination; Reaction time; Flexibility \\
\hline DEFENSIVE PHASE & Shot stopping; Coordination; Recovery; Speed; Save; Punch; Interceptions; Clearances; 1v1; Dive; \\
Technical & Vision; Organization; Communication; Distribution; Position play; Transition; Organize and coordinate \\
& team members; Positioning; Coordinate the defence; Develop and maintain situation awareness; \\
& $\begin{array}{l}\text { Restrict time and space of opposition; Maintain position in team structure; Gain possession; Manage } \\
\text { Tactical }\end{array}$ \\
& $\begin{array}{l}\text { members tempo; Play in line with coach ethos; Deny attacks; Manage defensive line; Organize team } \\
\text { opposition actions; Understand coach’s intent; Spatial awareness }\end{array}$ \\
\hline
\end{tabular}

Physical Height; Reaction time; Strength; Power; Agility; Coordination; Flexibility

Characteristics based on previously published studies [9, 28, 53, 59, 60]

pabilities. All these capacities can and should be optimized with good levels of reaction time, strength, power, and coordination. Additionally, as demonstrated in previous studies, structural height can be an advantage for players in this position.

The central defender (including the sweeper)

According to several studies $[9,11,28,34,46,53-56$, 61-64], the suggested profile of this position is characterized as shown in Table 7.

As indicated in the literature, the central defender will benefit from having well-developed technical skills such as heading, long passing, dribbling (attacking phase), as well as ball clearance, ball interception, and tackling (defensive phase) capabilities. In terms of tactical development, it is suggested that these players have a good view and read of the game as well as welltrained organizational and anticipatory capabilities. With reference to the playing area, they could take advantage of being exposed to actions within the defensive and midfield thirds. Regarding the physical aspects of this position, structural height, strength, speed, and power are important for these players to meet the demands of the game.
The full-back (or external defender)

According to several studies [9, 11, 34, 54, 56, 61-63] the suggested profile of this position can be characterized as described in Table 8.

The full-back, or external defender, is one of the least-explored positions in the literature. However, they have been described as players who will benefit from being strong at defensive clearances, interceptions, tackling, crossing, and backing. Full-backs should also have good passing skills. This position can take advantage of training time exposure within the defensive and midfield thirds. All of this should be balanced with physical features like acceleration, speed, power, agility, and stamina.

The midfielder (including the central defensive midfielder, holding midfielder, central midfielder, and central offensive midfielder)

According to several studies $[9,11,28,34,46,53-56$, 61-66], the suggested profile of this position can be characterized as presented in Table 9 .

The most detailed positional area in the literature is the midfield. It is suggested that the highly evident characteristics of a midfielder are as follows. Midfielders should have excellent dribbling and passing (in 


\section{HUMAN MOVEMENT}

T. Mota, R. Silva, F.M. Clemente, Holistic soccer profile by position

Table 7. Training contents framework for the central defender (including sweeper)

\begin{tabular}{ll}
\hline ATTACKING PHASE \\
\hline Technical & Heading; Long pass; Dribbling; Ball control; Passing; Running with the ball; Strong 1 to 1 play; \\
& Support play; Crossing; Shooting; Passes in the defensive third; Ball touches; Aerial duels; \\
& Passing accuracy; Effective passes; Receptions; Hold the ball; Protect the ball; First touch \\
\hline Tactical & Vision; Organization; Communication; Good view of the game; Organizing and anticipatory capabilities; \\
& Behaviours within the defensive and midfield thirds; Behaviours on the right side of the playing \\
& field; Ability to read game; Transition; Initiate build-up; Organize and coordinate team members; \\
& Positioning; Develop and maintain situation awareness; Maintain position in team structure; Maintain \\
& possession; Play in line with coach ethos; Delay attacks; Manage match tempo; Provide visual personal \\
& identification; Recognize/anticipate team member actions; Recognize/anticipate opposition actions; \\
& Understand coach’s intent; Spatial awareness; Attack at set pieces; Decision making \\
\hline Physical & Height; Strength; Speed; Power; Stamina; Agility \\
\hline
\end{tabular}

\section{DEFENSIVE PHASE}

Technical Heading; Clearances; Interceptions; 1 to 1 play and covering; Tackle; Defensive header; Aerial duels; Pressing opposition; Pressure ball carrier; Block shots

Tactical Vision; Organization; Communication; Good view of the game; Organizing and anticipatory capabilities; Behaviours on the right side of the playing field; Behaviours within the defensive and midfield thirds; Ability to read game; Transition; Organize and coordinate team members; Break up opposition attacks; Positioning; Retreat defence; Opposition offsides; Develop and maintain situation awareness; Restrict time and space of opposition; Maintain position in team structure; Gain possession; Play in line with coach ethos; Manage match tempo; Tactical fouls; Recognize/anticipate team member actions; Understand coach’s intent; Spatial awareness; Marking; Decision making

Physical Height; Strength; Speed; Power; Stamina; Agility

Characteristics based on previously published studies [9, 11, 28, 34, 46, 53-56, 61-64]

Table 8. Training contents framework for the full-back (or external defender)

\section{ATTACKING PHASE}

$\begin{array}{ll}\text { Technical } & \text { Crossing; Long pass; Ball touches; Tackle; Forward pass; Dribbling; Running with the ball; Aerial } \\ \text { duels; Passing; Throwing the ball back into play; Backing; Create goal scoring opportunities; Passing } \\ \text { accuracy; Effective passes; Duels; Block shots and crosses; Headers; Shots on goal; Successful 1v1; } \\ \text { Receptions; Hold the ball; Protect the ball; First touch }\end{array}$

Tactical Support play; When to cross; Running off the ball; Behaviours within the defensive and midfield thirds; Behaviours on the right side of the playing field; Communication; Transition; Initiate buildup; Positioning; Runs without the ball; Overlaps; Communication; Develop and maintain situation awareness; Maintain position in team structure; Maintain possession; Play in line with coach ethos; Delay attacks; Provide visual personal identification; Recognize/anticipate team member actions; Recognize/anticipate opposition actions; Understand coach’s intent; Spatial awareness; Break lines

Physical Speed; Power; Stamina; Acceleration; Agility

\section{DEFENSIVE PHASE}

Technical Clearances; Interceptions; Tackle; Pressing opposition; Defensive header; Aerial duels; Backing; Communication; Prevent attempts at goal and crosses; Pressure ball carrier; Successful 1v1

Tactical Support play; Running off the ball; Forcing offside; Behaviours within the defensive and midfield thirds; Behaviours on the right side of the playing field; Transition; Break up opposition attacks; Stretch opposition; Positioning; Retreat defence; Opposition offsides; Runs without the ball; Develop and maintain situation awareness; Communication; Restrict time and space of opposition; Maintain position in team structure; Gain possession; Play in line with coach ethos; Tactical fouls; Recognize/ anticipate team member actions; Recognize/anticipate opposition actions; Understand coach's intent; Spatial awareness; Break lines; Marking

Physical Speed; Power; Stamina; Acceleration; Agility

Characteristics based on previously published studies [9, 11, 46, 54, 56, 61-64] 
Table 9. Training contents framework for the midfielder (including central defensive midfielder, holding midfielder, central midfielder, and central offensive midfielder)

\begin{abstract}
ATTACKING PHASE
Technical Dribbling; Passing; Shooting; Short pass; Crossing; Ball touches; Ball receptions; Forward pass; Ball control; Good 1 to 1 play; Good technical skills; Creativity; Capability to achieve and shoot at the goal; Long pass; Dribble pass; Passes in the middle third; Passes to the left and right; Key pass; Running with the ball; Support play; Heading; Ball possession; Taking corners; Backing; Carrying the ball; Runs without the ball; Hold the ball; Protect the ball; Aerial challenges; Technique under pressure; First touch
\end{abstract}

Tactical Vision; Organization; Communication; Good view of the game; Behaviours within the midfield and attacking thirds; Behaviours on the right side of the playing field; Ability to read game; Decision making; Transition; Connect defence and attacking players; Assist and continue build-up; Bring attacking players into play; Provide attacking support; Positioning; Overlaps; Supporting runs; Switch the play; Develop and maintain situation awareness; Maintain position in team structure; Maintain possession; Manage match tempo; Play in line with coach ethos; Delay attacks; Recognize/ anticipate team member actions; Recognize/anticipate opposition actions; Understand coach's intent; Spatial awareness; Attack at set pieces; Open passing lanes; Switch field of play; Recognize when and how to support team members; Create space for self and team members; Free kicks; Recognize speed of game; Control speed of game; Decision making

Physical Speed; Stamina; Strength; Good running capabilities

DEFENSIVE PHASE

Technical Tackle; Interceptions; Pressing opposition; Heading; Good technical skills; Recoveries; Backing; Attacking play; Duels; Aerial challenges

Tactical Vision; Organization; Communication; Good view of the game; Behaviours within the midfield and attacking thirds; Behaviours on the right side of the playing field; Ability to read game; Decision making; Transition; Connect defence and attacking players; Disturb build-up; Protect central defence; Positioning; Retreat defence; Supporting runs; Press opposition attack; Press opposition defenders; Develop and maintain situation awareness; Restrict time and space of opposition; Maintain position in team structure; Gain possession; Manage match tempo; Play in line with coach ethos; Tactical fouls; Recognize/anticipate team member actions; Recognize/anticipate opposition actions; Understand coach's intent; Spatial awareness; Marking; Recognize when and how to support team members; Secondary ball wins; Pressure opposition; Recognize speed of game; Decision making

Physical Speed; Stamina; Strength; Good running capabilities

Characteristics based on previously published studies [9, 11, 28, 34, 46, 53-56, 61-66]

direction and distance) skills, accompanied by the capability to shoot and cross the ball, and they can be considered goo options to take corners. More defensive midfielders can benefit from being proficient in backing in the field and having good capabilities of holding and carrying the ball. In tactical terms, it is important for midfielders to have a good view and read of the game, capability of decision making, and organizational skills. Their behaviours normally occur within the midfield and attacking thirds, so it is suggested that this position might take advantage of exposure to these specific areas of the field. Strength, speed, and good running capabilities are believed to be crucial to optimize the aforementioned features.
The winger (including the right and left midfielder and winger)

According to several studies $[9,11,28,34,46,54-56$, 61-65], the suggested profile of this position can be characterized as shown in Table 10.

Wingers, or external midfielders, normally have their main presence and behaviours within the midfield and attacking thirds and the flanks of the field. As demonstrated in the literature, it is important that these players can position themselves well along the lateral extremes of the field. In technical aspects, wingers take advantage of having excellent dribbling, crossing, and shooting skills; they can be responsible for taking corners. Capacities like speed, power, strength, 


\section{HUMAN MOVEMENT}

T. Mota, R. Silva, F.M. Clemente, Holistic soccer profile by position

Table 10. Training contents framework for the winger (including right and left midfielder and winger)

\section{ATTACKING PHASE}

\begin{tabular}{ll}
\hline Technical & Dribbling; Crossing; Shooting; Ball touches; Ball reception; Passing; Running with the ball; Support \\
play; Good 1 to 1 play; Ground duels; Backwards pass; Key pass; Ball possession; Heading; Taking \\
corners; Carrying the ball; Create goal scoring opportunities; Passing accuracy; Effective passes; \\
Duels; Block shots and crosses; Headers; Shots on goal; Successful 1v1; Receptions; Hold the ball; \\
Protect the ball; Aerial challenges; Runs with the ball; Technique under pressure \\
\hline Tactical & Vision; Organization; Communication; Good flanks; Behaviours within the midfield and attacking \\
& thirds; Behaviours on the right side of the playing field; Initiate build-up; Positioning; Runs without \\
& the ball; Overlaps; Communication; Develop and maintain situation awareness; Maintain position \\
& in team structure; Maintain possession; Play in line with coach ethos; Delay attacks; Provide visual \\
& personal identification; Recognize/anticipate team member actions; Recognize/anticipate opposition \\
& actions; Understand coach’s intent; Spatial awareness; Break lines
\end{tabular}

Physical Speed; Stamina; Power; Strength; Good physical condition; Acceleration; Agility

\section{DEFENSIVE PHASE}

Technical Tackle; Pressing opposition; Full-back cover; Interceptions; Heading; Prevent attempts at goal
and crosses; Pressure ball carrier; Successful 1v1; Aerial challenges

Tactical Vision; Organization; Communication; Good flanks; Behaviours within the midfield and attacking thirds; Behaviours on the right side of the playing field; Break up opposition attacks; Stretch opposition; Positioning; Retreat defence; Opposition offsides; Runs without the ball; Develop and maintain situation awareness; Communication; Restrict time and space of opposition; Maintain position in team structure; Gain possession; Play in line with coach ethos; Tactical fouls; Recognize/anticipate team member actions; Recognize/anticipate opposition actions; Understand coach's intent; Spatial awareness; Break lines; Marking

Physical Speed; Stamina; Power; Strength; Good physical condition; Acceleration; Agility

Characteristics based on previously published studies [9, 11, 28, 34, 46, 54-56, 61-65]

Table 11. Training contents framework for the forward (or striker)

\section{ATTACKING PHASE}

Technical Shooting; Finishing; Heading; Reception; Dribbling; Interception; Passing; Running with the ball; Support play; Crossing; Ball control; Tricks; Good goal-getter qualities; Good 1 to 1 play; Ground duels; Key pass; Aerial duels; Ball possession; Ability of single play; Creativity; Runs with the ball; Hold the ball; Protect the ball; First touch

Tactical Vision - awareness of space; Anticipation; Organization; Communication; Behaviours within the attacking third; Behaviours within central areas; Bring others into offensive situations; Assist in goal scoring; Positioning; Runs without the ball; Overlaps; Provide visual personal identification; Recognize/anticipate team member actions; Recognize/anticipate opposition actions; Understand coach's intent; Spatial awareness; Create space for self and team members; Stretch opposition defensive lines; Get into scoring positions

Physical Speed; Agility; Power; Strength; Stamina; High velocity; Height

\section{DEFENSIVE PHASE}

Technical Heading; Interception; Tackle; Pressing opposition; Aerial duels

Tactical Vision - awareness of space; Anticipation; Organization; Communication space; Organization; Communication; Behaviours within the attacking third; Behaviours within central areas; Initiate disturb build-up of opposition; Positioning; Runs without the ball; Press opposition defenders; Recognize/anticipate team member actions; Recognize/anticipate opposition actions; Understand coach's intent; Spatial awareness; Pressure opposition; Close passing lanes

Physical Speed; Agility; Power; Strength; Stamina; High velocity; Height

Characteristics based on previously published studies [9, 11, 28, 34, 46, 54-56, 61-66] 
acceleration, and agility can benefit athletes who play this role.

\section{The forward (or striker)}

According to several studies [9, 11, 28, 34, 46, 54-56, 61-66], the suggested profile of this position can be characterized as described in Table 11.

The most advanced position on the field, the forward, is normally occupied by a player who has an attacking mindset and strong technical skills. As indicated in the studies mentioned above, qualities like shooting, heading, ball reception, creativity, individual plays, and dribbling are technical features that a striker will benefit from. Vision-awareness of space, anticipation, and exposure to actions in the central attacking third of the field are tactical characteristics that will be of use to players in this position during the game. In terms of physical attributes, high velocity and agility are of significant importance for strikers.

\section{Conclusions}

The theoretical framework proposed in this article is intended to help coaches easily identify the training requirements of each playing position. The model is meant to represent the current literature on the theme and establish a bridge between the research and the operational realm of our field. Naturally, more specific work should be conducted to consider the best model of play or even the individualization principle in accordance with each player's needs. With regard to the built framework, the characteristics presented in this paper are those that the authors found to be the most relevant to the structure. This does not imply that these are the main attributes to be trained across the positions in all teams, but they can be considered as general guidelines.

Our proposal was limited to the literature search and the availability of relevant works. In terms of technical and tactical characteristics, there were positions that were described in more detail than others. Specifically, we observed a lack of research on some positions, namely goalkeepers, full-backs, and wingers. Furthermore, some aspects can represent future important items to investigate:

- a possible systematic review on the individualization training process;

- a practical guideline of which exercises can implement a more individual training approach;

- a more detailed research on the psychological content of training within each position;
- better insights into the attributes of the goalkeeper, full-back, and winger positions, as well as more detailed information on the different phases of the game (attacking and defensive).

In addition to possibly being an assistant tool for coaches in planning and prescribing a more individualized training, this framework might also be useful to aid coaching and scouting staff in identifying talent since it could represent a more qualitative assessment of a player's potential for a certain position.

\section{Ethical approval}

The conducted research is not related to either human or animal use.

\section{Disclosure statement}

No author has any financial interest or received any financial benefit from this research.

\section{Conflict of interest}

The authors state no conflict of interest.

\section{References}

1. Steenbeek HW, van Geert PLC. A theory and dynamic model of dyadic interaction: concerns, appraisals, and contagiousness in a developmental context. Dev Rev. 2007;27(1):1-40; doi: 10.1016/j.dr.2006.06.002.

2. Beebe B, Jaffe J, Lachmann FM. A dyadic systems view of communication. In: Skolnick NJ, Warshaw SC (eds.), Relational perspectives in psychoanalysis. London: Routledge; 2015; 61-82.

3. Gréhaigne J-F, Bouthier D, David B. Dynamic-system analysis of opponent relationships in collective actions in soccer. J Sports Sci. 1997;15(2):137-149; doi: 10.1080/ 026404197367416.

4. Gréhaigne J-F, Godbout P, Zerai Z. How the "rapport de forces" evolves in a soccer match: the dynamics of collective decisions in a complex system. Rev Psicol Deporte. 2011;20(2):747-765.

5. Low B, Coutinho D, Gonçalves B, Rein R, Memmert D, Sampaio J. A systematic review of collective tactical behaviours in football using positional data. Sports Med. 2020;50(2):343-385; doi: 10.1007/s40279-01901194-7.

6. Gonçalves BV, Figueira BE, Maçãs V, Sampaio J. Effect of player position on movement behaviour, physical and physiological performances during an 11-a-side football game. J Sports Sci. 2014;32(2):191-199; doi: 10.1080/02640414.2013.816761.

7. Clemente FM, Couceiro MS, Martins FML, Mendes R, Figueiredo AJ. Measuring collective behaviour in football teams: inspecting the impact of each half of the match on ball possession. Int J Perform Anal Sport. 2013;13(3):678-689; doi: 10.1080/24748668.2013.118 68680 . 
T. Mota, R. Silva, F.M. Clemente, Holistic soccer profile by position

8. Sampaio J, Maçãs V. Measuring tactical behaviour in football. Int J Sports Med. 2012;33(5):395-401; doi: 10.1055/s-0031-1301320.

9. Berber E, McLean S, Beanland V, Read GJM, Salmon PM. Defining the attributes for specific playing positions in football match-play: a complex systems approach. J Sports Sci. 2020;38(11-12):1248-1258; doi: 10.1080/02640414.2020.1768636.

10. Bradley PS, Carling C, Archer D, Roberts J, Dodds A, Di Mascio M, et al. The effect of playing formation on high-intensity running and technical profiles in English FA Premier League soccer matches. J Sports Sci. 2011;29(8):821-830; doi: 10.1080/02640414.2011.56 1868.

11. Roberts SJ, McRobert AP, Lewis CJ, Reeves MJ. Establishing consensus of position-specific predictors for elite youth soccer in England. Sci Med Football. 2019; 3(3):205-213; doi: 10.1080/24733938.2019.1581369.

12. Castelo J. Football. Dynamic organization of the game [in Portuguese]. Lisboa: Edições FMH; 2004.

13. Castelo J. Football. Technical and tactical model of the game. Identification and characterization of major trends in the evolution of teams of superior performance [in Portuguese]. Lisboa: Edições FMH; 1992.

14. Teoldo da Costa I, Garganta da Silva JM, Greco PJ, Mesquita I. Tactical principles of soccer: concepts and application. Mot Rev Educ Fis. 2009;15(3):657-668; doi: $10.5016 / 2488$.

15. Castelo J. Football. Organization of the game [in Portuguese]. Lisboa: Visão e Contextos; 1996.

16. Gréhaigne J-F, Richard J-F, Griffin LL. Teaching and learning team sports and games. New York: Routledge; 2005.

17. Paul DJ, Bradley PS, Nassis GP. Factors affecting match running performance of elite soccer players: shedding some light on the complexity. Int J Sports Physiol Perform. 2015;10(4):516-519; doi: 10.1123/IJSPP.2015 -0029 .

18. Metaxas TI. Match running performance of elite soccer players: $\mathrm{VO}_{2} \max$ and players position influences. J Strength Cond Res. 2021;35(1):162-168; doi: 10.1519/ JSC.0000000000002646.

19. Bangsbo J, Mohr M, Krustrup P. Physical and metabolic demands of training and match-play in the elite football player. J Sports Sci. 2006;24(7):665-674; doi: 10.1080/02640410500482529.

20. Clemente FM, Owen A, Serra-Olivares J, Nikolaidis PT, van der Linden CMI, Mendes B. Characterization of the weekly external load profile of professional soccer teams from Portugal and the Netherlands. J Hum Kinet. 2019;66(1):155-164; doi: 10.2478/hukin-2018-0054.

21. Andrzejewski M, Chmura J, Pluta B, Konarski JM. Sprinting activities and distance covered by top level Europa League soccer players. Int J Sports Sci Coach. 2015;10(1):39-50; doi: 10.1260/1747-9541.10.1.39.

22. Djaoui L, Chamari K, Owen AL, Dellal A. Maximal sprinting speed of elite soccer players during training and matches. J Strength Cond Res. 2017;31(6):1509_ 1517; doi: 10.1519/JSC.0000000000001642.

23. Bradley PS, Sheldon W, Wooster B, Olsen P, Boanas P, Krustrup P. High-intensity running in English FA Premier League soccer matches. J Sports Sci. 2009;27(2): 159-168; doi: 10.1080/02640410802512775.

24. Rampinini E, Coutts AJ, Castagna C, Sassi R, Impellizzeri FM. Variation in top level soccer match performance. Int J Sports Med. 2007;28(12):1018-1024; doi: 10.1055/s-2007-965158.

25. Baptista I, Johansen D, Seabra A, Pettersen SA. Position specific player load during match-play in a professionalfootballclub.PLoSOne.2018;13(5):e0198115; doi: 10.1371/journal.pone.0198115.

26. Palucci Vieira LH, Carling C, Barbieri FA, Aquino R, Pereira Santiago PR. Match running performance in young soccer players: a systematic review. Sports Med. 2019;49(2):289-318; doi: 10.1007/s40279-018-01048-8.

27. Salter J, De Ste Croix MBA, Hughes JD. The moderating impact of maturation on acute neuromuscular and psycho-physiological responses to simulated soccer activity in academy soccer players. Eur J Sport Sci. 2020;111; doi: 10.1080/17461391.2020.1851775.

28. Vigne G, Gaudino C, Rogowski I, Alloatti G, Hautier C. Activity profile in elite Italian soccer team. Int J Sports Med. 2010;31(5):304-310; doi: 10.1055/s-0030-124 8320 .

29. Di Salvo V, Baron R, Tschan H, Calderon Montero FJ, Bachl N, Pigozzi F. Performance characteristics according to playing position in elite soccer. Int J Sports Med. 2007;28(3):222-227; doi: 10.1055/s-2006-924294.

30. Dalen T, Ingebrigtsen J, Ettema G, Havard Hjelde G, Wisløff U. Player load, acceleration, and deceleration during forty-five competitive matches of elite soccer. J Strength Cond Res. 2016;30(2):351-359; doi: 10.1519/ JSC.0000000000001063.

31. Ingebrigtsen J, Dalen T, Havard Hjelde G, Drust B, Wisløff U. Acceleration and sprint profiles of a professional elite football team in match play. Eur J Sport Sci. 2015;15(2):101-110; doi: 10.1080/17461391.2014. 933879.

32. Tierney PJ, Young A, Clarke ND, Duncan MJ. Match play demands of 11 versus 11 professional football using Global Positioning System tracking: variations across common playing formations. Hum Mov Sci. 2016; 49:1-8; doi: 10.1016/j.humov.2016.05.007.

33. Miñano-Espin J, Casáis L, Lago-Peñas C, Gómez-Ruano MÁ. High speed running and sprinting profiles of elite soccer players. J Hum Kinet. 2017;58:169-176; doi: 10.1515/hukin-2017-0086.

34. Dellal A, Wong DP, Moalla W, Chamari K. Physical and technical activity of soccer players in the French First League - with special reference to their playing position. Int SportMed J. 2010;11(2):278-290.

35. Gregson W, Drust B, Atkinson G, Salvo VD. Match-tomatch variability of high-speed activities in premier league soccer. Int J Sports Med. 2010;31(4):237-242; doi: 10.1055/s-0030-1247546. 
36. Boone J, Vaeyens R, Steyaert A, Vanden Bossche L, Bourgois J. Physical fitness of elite Belgian soccer players by player position. J Strength Cond Res. 2012;26(8):20512057; doi: 10.1519/JSC.0b013e318239f84f.

37. Bizati O. Physical and physiological characteristics of an elite soccer team's players according to playing positions. Anthropologist. 2016;26(3):175-180; doi: 10.1080/ 09720073.2016.11892146.

38. Reilly T, George K, Marfell-Jones M, Scott M, Sutton L, Wallace JA. How well do skinfold equations predict percent body fat in elite soccer players? Int J Sports Med. 2009;30(8):607-613; doi: 10.1055/s-0029-1202353.

39. Tønnessen E, Hem E, Leirstein S, Haugen T, Seiler S. Maximal aerobic power characteristics of male professional soccer players, 1989-2012. Int J Sports Physiol Perform. 2013;8(3):323-329; doi: 10.1123/ijspp.8.3.323.

40. Arnason A, Sigurdsson SB, Gudmundsson A, Holme I, Engebretsen L, Bahr R. Physical fitness, injuries, and team performance in soccer. Med Sci Sports Exerc. 2004;36(2):278-285;doi:10.1249/01.MSS.0000113478. 92945.CA.

41. Al-Hazzaa HM, Almuzaini KS, Al-Refaee SA, Sulaiman MA, Dafterdar MY, Al-Ghamedi A, et al. Aerobic and anaerobic power characteristics of Saudi elite soccer players. J Sports Med Phys Fitness. 2001;41(1):54-61.

42. Nikolaidis PT. Can maximal aerobic running speed be predicted from submaximal cycle ergometry in soccer players? The effects of age, anthropometry and positional roles. Adv Biomed Res. 2015;4(1):226; doi: 10.4103/22779175.166649.

43. Wisløff U, Castagna C, Helgerud J, Jones R, Hoff J. Strong correlation of maximal squat strength with sprint performance and vertical jump height in elite soccer players. Br J Sports Med. 2004;38(3):285-288; doi: 10.1136/bjsm.2002.002071.

44. Helgerud J, Engen LC, Wisløff U, Hoff J. Aerobic endurance training improves soccer performance. Med Sci Sports Exerc. 2001;33(11):1925-1931; doi: 10.1097/ 00005768-200111000-00019.

45. Reilly T, Bangsbo J, Franks A. Anthropometric and physiological predispositions for elite soccer. J Sports Sci. 2000;18(9):669-683; doi: 10.1080/02640410050 120050.

46. Rebelo A, Brito J, Maia J, Coelho-e-Silva MJ, Figueiredo AJ, Bangsbo J, et al. Anthropometric characteristics, physical fitness and technical performance of under-19 soccer players by competitive level and field position. Int J Sports Med. 2013;34(4):312-317; doi: 10.1055/s-0032-1323729.

47. Haugen TA, Tønnessen E, Seiler S. Speed and countermovement-jump characteristics of elite female soccer players, 1995-2010. Int J Sports Physiol Perform. 2012; 7(4):340-349; doi: 10.1123/ijspp.7.4.340.

48. Halvorsen Wik E, Mc Auliffe S, Read PJ. Examination of physical characteristics and positional differences in professional soccer players in Qatar. Sports. 2018; 7(1):9; doi: 10.3390/sports7010009.
49. Jezdimirović M, Joksimović A, Stanković R, Bubanj S. Differences in the vertical jump in soccer players according to their position on the team. Facta Univ Ser Phys Educ Sport. 2013;11(3):221-226.

50. Kulkarni K, Levin GT, Penailillo L, Singh A, Singh SJ. Physical and physiological characteristics of elite Indian national football players. J Athl Enhancement. 2013;2:6; doi: 10.4172/2324-9080.1000128.

51. Pivovarniček P, Pupiš M, Lacena M. A level of jump abilities of elite Slovak soccer players at different positions in field. J Phys Educ Sport. 2015;15(1):53-56; doi: 10.7752/jpes.2015.01009.

52. Sporis G, Jukic I, Ostojic SM, Milanovic D. Fitness profiling in soccer: physical and physiologic characteristics of elite players. J Strength Cond Res. 2009;23(7): 1947-1953; doi: 10.1519/JSC.0b013e3181b3e141.

53. Deprez D, Fransen J, Boone J, Lenoir M, Philippaerts R, Vaeyens R. Characteristics of high-level youth soccer players: variation by playing position. J Sports Sci. 2015; 33(3):243-254; doi: 10.1080/02640414.2014.934707.

54. Hughes M, Caudrelier T, James N, Redwood-Brown A, Donnelly I, Kirkbride A, et al. Moneyball and soccer an analysis of the key performance indicators of elite male soccer players by position. J Hum Sport Exerc. 2012;7(2):402-412; doi: 10.4100/jhse.2012.72.06.

55 . Wiemeyer J. Who should play in which position in soccer? Empirical evidence and unconventional modelling. Int J Perform Anal Sport. 2003;3(1):1-18; doi: 10.1080/ 24748668.2003.11868269.

56. Razali N, Mustapha A, Yatim FA, Ab Aziz R. Predicting player position for talent identification in association football.IOPConfSerMater SciEng. 2017;226:012087; doi: 10.1088/1757-899X/226/1/012087.

57. Varley MC, Gregson W, McMillan K, Bonanno D, Stafford K, Modonutti M, et al. Physical and technical performance of elite youth soccer players during international tournaments: influence of playing position and team success and opponent quality. Sci Med Football. 2017;1(1):18-29;doi:10.1080/02640414.2016.1230676.

58. Haff GG, Triplett NT (eds.). Essentials of strength training and conditioning. Champaign: Human Kinetics; 2015.

59. West J. A review of the key demands for a football goalkeeper. Int J Sports Sci Coach. 2018;13(6):1215-1222; doi: 10.1177/1747954118787493.

60. Hughes MG, Birdsey L, Meyers R, Newcombe D, Oliver JL, Smith PM, et al. Effects of playing surface on physiological responses and performance variables in a controlled football simulation. J Sports Sci. 2013; 31(8):878-886; doi: 10.1080/02640414.2012.757340.

61. Taylor JB, Mellalieu SD, James N. Behavioural comparisons of positional demands in professional soccer. Int J Perform Anal Sport. 2004;4(1):81-97; doi: 10.1080/ 24748668.2004.11868294.

62. Yi Q, Jia H, Liu H, Gómez MÁ. Technical demands of different playing positions in the UEFA Champions League. Int J Perform Anal Sport. 2018;18(6):926-937; doi: $10.1080 / 24748668.2018 .1528524$. 


\section{HUMAN MOVEMENT}

T. Mota, R. Silva, F.M. Clemente, Holistic soccer profile by position

63. Ermidis G, Randers MB, Krustrup P, Mohr M. Technical demands across playing positions of the Asian Cup in male football. Int J Perform Anal Sport. 2019;19(4): 530-542; doi: 10.1080/24748668.2019.1632571.

64. Taylor BJ, Mellalieu DS, James N. A comparison of individual and unit tactical behaviour and team strategy in professional soccer. Int J Perform Anal Sport. 2005; 5(2):87-101; doi: 10.1080/24748668.2005.11868329.

65. Gioldasis A, Souglis A, Christofilakis O. Technical skills according to playing position of male and female soccer players. Int J Sci Cult Sport. 2017;5(4):293-301; doi: 10.14486/IntJSCS688.

66. Bloomfield J, Polman R, O’Donoghue P. Physical demands of different positions in FA Premier League soccer. J Sports Sci Med. 2007;6(1):63-70. 